\title{
Integrating Technology in Teaching and Learning Mathematics
}

\author{
Paulina Pannen \\ Directorate General of Higher Education Ministry of Education and Culture Indonesia \\ <ppanen@gmail.com>
}

\begin{abstract}
With the rapid development of ICT and its ramification in our world, especially education, can we envision how education will look like in the future, especially in Indonesia, and in the teaching and learning of mathematics? Employing Zappa's Envisioning the Future of Educational Technology (2013) and NMC Horizon Report (2014) K-12 Edition, this paper will reflect on the effort of ICT integration in teaching and learning, especially in the teaching and learning of mathematics, in Indonesia. Taking stock of the existing Government's policy on ICT and ICT in Education, also of the facts and figures of Indonesia's ICT profile, this paper discusses initiatives, practices, and studies of ICT in Education, integration of ICT in the teaching and learning of mathematics, what technology and how to integrate in the teaching and learning of mathematics, and some future prediction on the evolution of teaching and learning due to emerging technologies.
\end{abstract}

Keywords: ICT, Education, Technology

\section{Introduction}

ICTs have become one of the essential pillars of modern society, therefore, the mastery and understanding ICT basic skills and concepts is imperative. With the rapid development of ICTs and their ramification in our world, especially education, can we envision how will education look like in the future, especially in Indonesia, and in the teaching and learning of mathematics? Ten years ago, smartphones were a luxury, and tablets did not even exist. This rapid development is also combined with our internal challenges to implement the 2013 Curriculum, which calls for reform in teaching and learning practices. How will these challenges impact upon mathematics teachers in Indonesia?

Employing Zappa’s (2013) envisioning the future of educational technology and NMC Horizon Report (Johnson, Adams-Becker, Estrada, \& Freeman, 2014) this paper will reflect upon the effort of ICT integration in teaching and learning, especially in the teaching and learning of mathematics, in Indonesia. 


\section{Policy}

The use of ICT in teaching and learning has been encouraged in Indonesia, despite the fact that access to ICT has not been distributed equally to all teachers and students, and schools across Indonesia. The connection issue (broadband, ISP, etc.), acquisition of hardware (which depends on institutional and financial support), software, and human ware are not yet equally available. The Government of Indonesia has made serious efforts to provide access to ICT, in terms hardware, software programs, and infrastructure to all education institutions for more than two decades. Change is happening incrementally, but these adjustments will need to be intensified at comparable speed with the technology development.

The policy on ICT in Education was part of the 2001 Presidential Decree on Telematics. Later, issued in 2003, the Law of National Education lists ICT as one modality to deliver education both in face-to-face education as well as in a distance education environment. In 2005, the Law on Teachers and Lecturers promotes ICT competency for teachers and lecturers as part of their professionalism. In 2006, 441 ICT centers were established in vocational and general high schools. The site E-dukasi.net is one ICT based program which was then developed by the Center for Information and Communication Technology for Education (Pustekkom) to offer multimedia and web-based materials for students of grade 7 to 12, and for vocational schools. Materials for school subjects are completed with exercises and tests.

In year 2006 National ICT Board has prioritize E-education as one of its flagship program (Nandika, Priowirjanto, \& Soekartawi, 2007). The introduction of ICT to schools has since been carried out by various parties, involving both private and public agents. Furthermore, the national education network (National ICT Backbone) and information system (Jardiknas \& Inherent) were also established to serve integrated educational services in the provinces, cities, universities, and schools. In parallel to these development, there is also growing interest in open and distance education which was marked by the establishment of Universitas Terbuka in 1984, mainly serving in-service teachers and teachers' qualification upgrading and the establishment of open junior high school and open senior high school; the use of open educational resources, ICT based distance education for teachers (HYLITE), and ICT-based resource sharing and collaboration (e-books, e-journals, e-library). 


\section{Facts and Figures}

As an archipelago Indonesia covers 5,193,252 square kilometers of 17,508 islands with three time zones. It has 80,000 kilometers of shoreline and is the fourth most populous country in the world with an estimated 253,899,536 population. The population represents more than 500 ethnic groups. The country is demographically unique and different, and geographically vast with its people practicing different cultures and traditions.

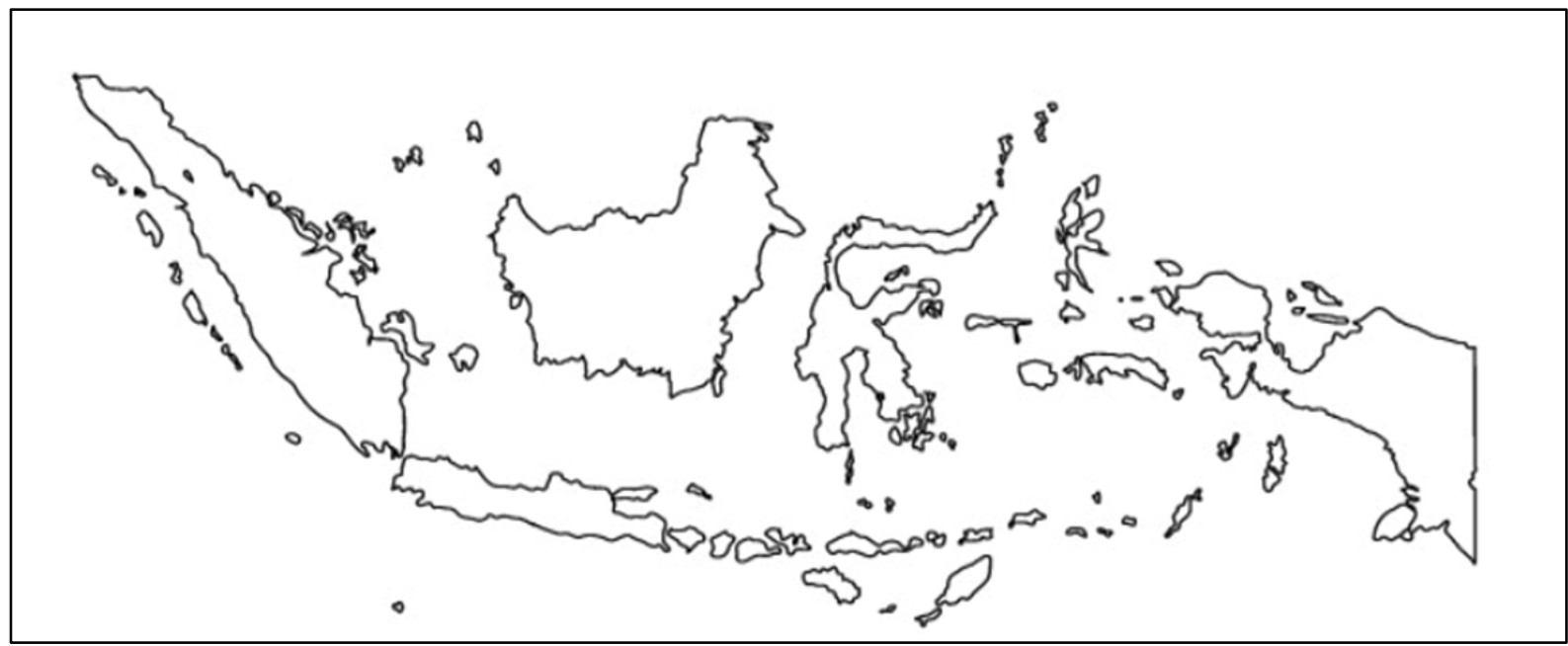

Figure 1: Map of Indonesia

About 88 percent of Indonesians are Muslims. The rest are Christians (8\%), Hindus (2\%) and those of other religions (2\%). Hence, Indonesia is thus the world's most populous Muslim-majority country. Jakarta, the capital city of Indonesia is also the most populous in Southeast Asia and the 13th most populated city on earth. The official metropolitan area is populated by more than 28 million people.

The country is characterized by four core problems: diversity, disparity, scalability, and sustainability (Nizam \& Santoso, 2013). Its diversity results from having more than 300 ethnic groups speaking more than 500 languages and dialects. This means that every district is unique and different from each other. The imbalance in physical development of the country through the course of history contributes to the disparity

Despite these problems, ICT in Indonesia is developing rapidly. Lukman (2013) states that Indonesia has as many as 41.3 million smartphone and 6 million tablet owners by the end of 2013 and that the numbers are predicted to increase to 103.7 million smartphone and 16.2 million tablet users by 2017. Meanwhile, there were 74.6 million Internet users, that is, around 25\% percent penetration rate. Out of these, $80 \%$ are Facebook subscribers. Almost 
half of Indonesian netizens are below 30 years old, while those above 45 years old make up 16.7 percent of Indonesian netizens. About 86 percent of the netizens access the Internet using smartphones and spend between IDR 50,000 (USD5) and IDR 100,000 (USD 10) monthly for Internet access. They mostly go online to socialize (38\%), chat (28\%), listen to music (21\%) and play games (19\%). About 17 percent are reading content. The majority of these internet users tend to come from those living in cities and large towns.

\section{ICT in Education}

Schooling in Indonesia covers around 290.000 schools, 51.3 million students, and 3.7 million teachers, with learner to computer ratio of 136 students for one computer. The use of computers in school started primarily for administrative purposes. Several schools, especially private ones and those in large cities, have developed school websites for promotion and communication between school and its community. However, the application of ICT to teaching-learning activities is prevalent in few schools, usually only international schools or branches of foreign school systems. A survey conducted by the Centre for Information and Communication Technology in Education (PUSTEKKOM) of schools in Jakarta found the use of ICT in Indonesian schools has been part of the curriculum at all school level. Although there is no specific hours dedicated at primary level, there are about 5-10 hours dedicated for ICT learning in junior and senior secondary school (UIS, 2014). In the 2013 curriculum, the use of ICT has been integrated across subjects, instead of a mere standalone course. Regardless of the increasing internet penetration rate and use of ICT gadgets and social media, the use of ICT in education, especially in teaching and learning is considerably low, along with low supporting infrastructure (UIS, 2014).

The use of ICT has followed different stages since early years in the early 2000 up to the present years, but mostly indicates that ICT is being used as enhancement to the traditional face-to-face learning as follows:

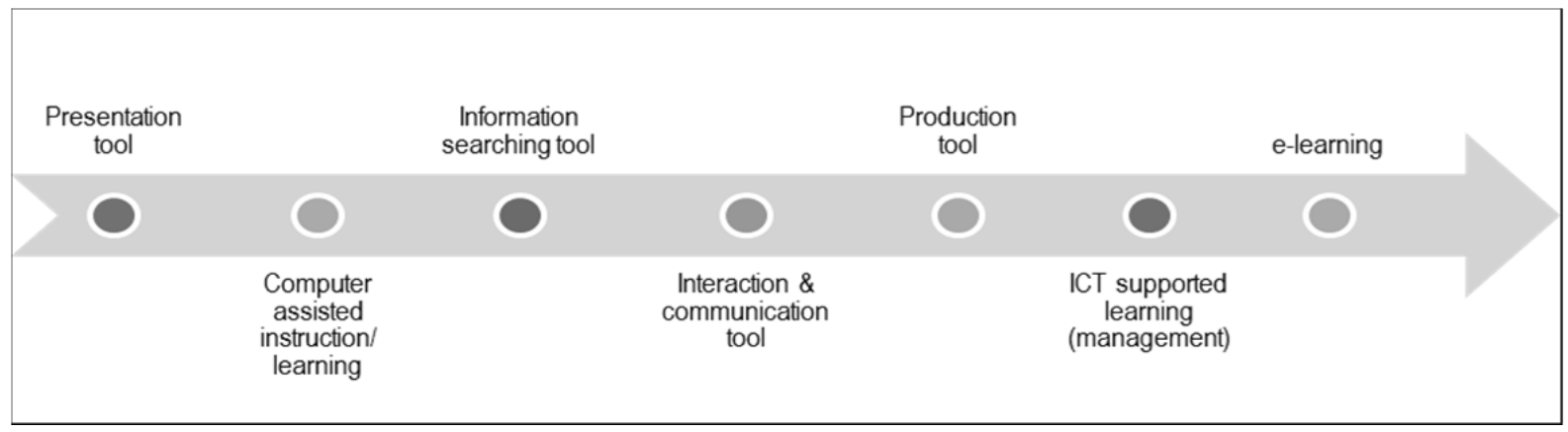

Figure 2: Stages of ICT use (Adapted from Pannen, 2009) 
The stages depict the incremental progression of the use of ICT as a tool for teaching and learning, from the most simple to the presently most sophisticated use and from single media to the integrated multimedia use to enhance and facilitate what is essentially a face-toface teaching and learning. From the perspective of teachers, this progression has usually been the case when ICT use is at the (newly) emerging and/or applying stages, instead of infusing or transforming level. The infusing and transforming level usually involve teachers' use of ICT in all aspects of their professional life, and daily life, beyond school. A number of research studies have been conducted based on this framework and resulted in a general consensus that the use of ICT in teaching and learning brings about positive benefits in student learning (Wahyudi, 2008). A study by Harrison et al. (2002), also provides concrete evidence of ICT having an impact on teaching and learning in the classroom

The global movement of $21^{\text {st }}$ Century learning as well as the 2013 Curriculum in Indonesia have called for more strategic use of ICT in teaching and learning: an ICT-based teaching and learning, where ICT is no longer a mere facilitator to teaching and learning (ICT-supported teaching and learning or ICT-enhanced teaching and learning), but an integrated component of teaching and learning in various subjects. The questions arise from teachers then: What exactly is the potential of ICT for learning and teaching; how best to exploit this potential in education, especially mathematics education; does digital technology really work?

When designed properly, there are numerous potential uses of ICT in education. As an integrated component of teaching and learning, ICT allows learning experiences which are innovative, accelerated, enriched, and deepen the skills acquisition, motivating and engaging and relating school experience to work practices and an authentic context. The integration of ICT can help teachers and students to embark on the student-centered learning instead of content-oriented or teacher-centered learning. Microsoft (2014) elaborates that ICT use in teaching and learning has the potential for developing self-regulation, collaboration, knowledge construction, real-world problem-solving and innovation, and skilled communication. These potential uses of ICT in education indicate that the simple use of ICT as a tool in teaching and learning is no longer adequate, and thus creative and innovative strategy on the use of ICT is required. 
The NMC Horizon Report (Johnson, et al., 2014) has summarized the strategy of creating creative teaching and learning through the use of ICT as depicted in the following figure:

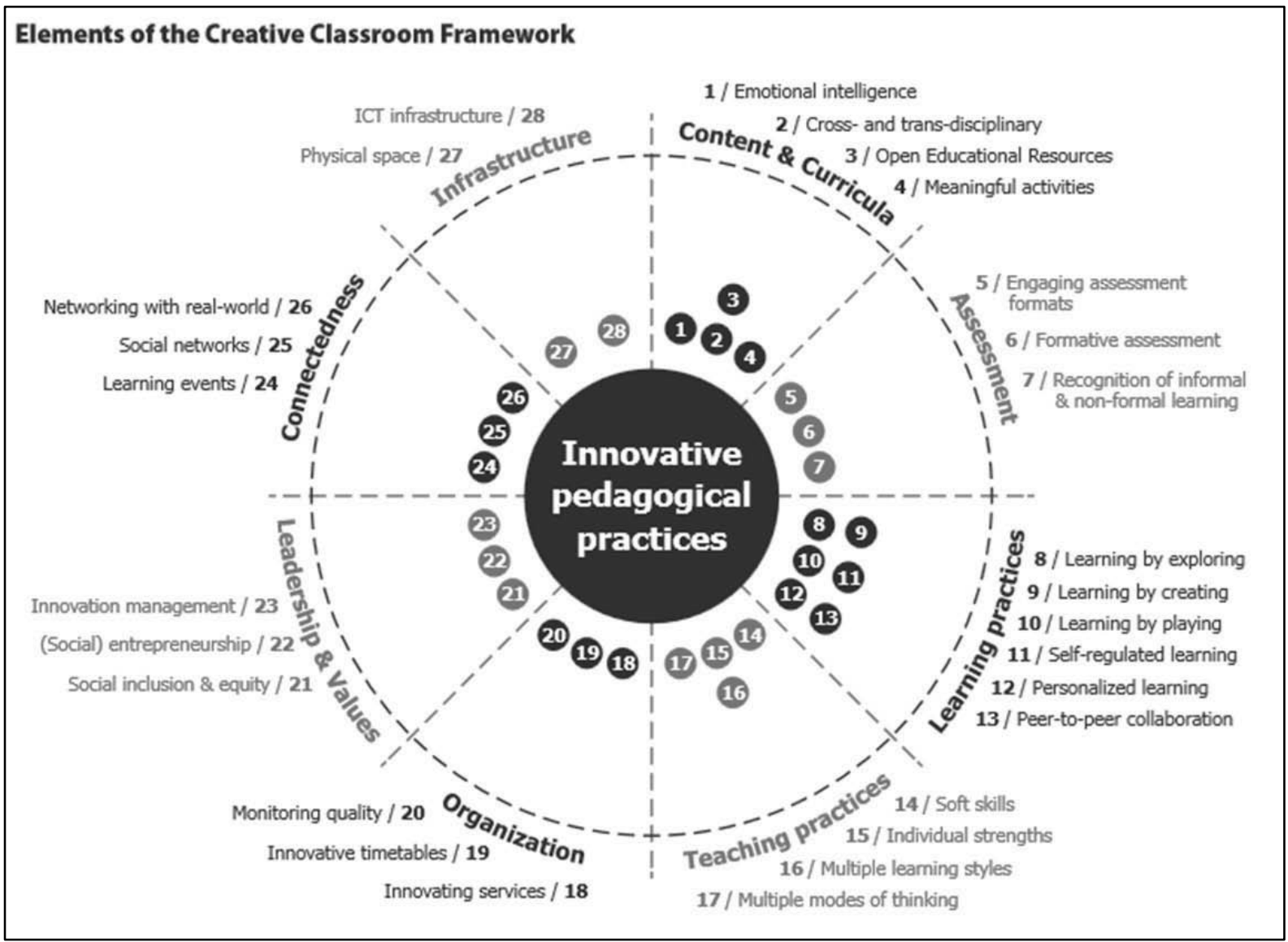

Figure 3: Creative Classroom Framework using ICT (http://cdn.nmc.org/media/2014-nmc-horizon-

report-k12-EN.pd The use of ICT has enabled teachers to be innovative and creative in developing content and curricula through the use and production of cross and transdisciplinary open educational resources, to be employed in meaningful activities which challenges students' emotional intelligence. It also enables teachers to innovative and creative evaluator and assessor of learning outcomes, to employ engaging assessment format, various formative assessment, and to recognize prior learning experience. The use of ICT plays key role in innovative and creative learning practices to allow students to learn by exploring, by creating, by playing, by self-regulating, by personalized learning, and by peer collaboration. It also plays important role in innovative and creative teaching practices to include the teaching of soft skills, to cultivate individual strengths, to cater multiple learning styles, and to accommodate multiple modes of thinking. The next important role of use of 
ICT in teaching and learning is the connectedness, making a classroom that no longer brick walls boundaries because it opens the window to the world.

All strategies have been extensively integrating ICT into education, even turning the classroom into a different form, i.e., the blended learning form, where face-to-face teaching and learning is no longer the most dominating mode of learning. The most recent strategy which integrates ICT into teaching and learning has been the so-called "flip-learning". Examples of this flip-learning or flipping the classroom have been demonstrated by the Khan Academy (http://www.edutopia.org/khan-academy-discovery-lab-blended-learningvideo). The Khan Academy provides numerous learning content in multiple forms, which students or teachers can download and then learn at their own place, time, and pace, before the face-to-face meeting. Thus, the face-to-face meeting that follows will be used mainly for discussion, simulation, practices, or creation of learning products. As such, the low level learning of memorizing and understanding of learning content can be done at home, prior to the meeting. The meeting at school becomes important session as student will be engaged in higher order learning through various meaningful activities.

In Indonesia, a portal similar to Khan Academy is available, i.e., the EdukasiNet and Rumah Belajar. In addition, teachers are welcome to use other sites, as well as Khan Academy itself, to enrich their learning materials, based on the learning outcomes and basic competencies to be achieved. What is needed, then, is the creativity of the teachers to mix and match the rich learning resources available into the teaching and learning process and implement an ICT-based teaching and learning.

In general, the use of ICT in teaching and learning has implications for how teaching is planned and carried through. With the use of ICT, there is need for new approaches to the teaching, new tasks and problems for the students to work on and perhaps new ways of working and learning together. To be able to integrate ICT in teaching and learning, to use ICT properly and creatively, teachers are expected to believe in the effectiveness of ICT as has been proven by numerous studies. Further, teachers should believe that the use of technology will not cause any disturbances in their teaching and learning, on the other hand it will make the teaching and learning more meaningful, fun, and efficient. Finally teachers should believe that they have control over technology, as nothing could replace the role of the human touch of a teacher as a learning designer. Johnson et al, (2014) asks: What is the role of a teacher in such a scenario? $\mathrm{His}$ answer is that we need to put 
aside the traditional knowledge acquisition model. The main effort of teaching shifts to designing learning environments that enable the students to realize on their own what they need to know in order to achieve certain competencies.

Many research and studies show that most teachers do not make use of the potential of ICT to contribute to the quality of learning environments, although they value this potential quite significantly, because of their beliefs which are contradictory to the expected (Amin, n.d.). According to MNC Report (Johnson, et al., 2014), the key to nurturing the new role of teachers and developing the teachers' belief in the use of ICT is providing them with plentiful opportunities for professional development, to allow upskilling and reskilling.

\section{Integration of ICT in the Teaching and Learning of Mathematics}

ICT has been considered an essential tool for learning mathematics in the 21st century. The National Council of Teachers of Mathematics (2008) states that USA schools must ensure that all their students have access to technology. Hoyles \& Lagrange (2010) state that digital technologies were becoming ever more ubiquitous and their influence touching most, if not all, education systems.

Drijvers, Boon and Van Reeuwijk (2010) distinguish three main didactical functionalities for ICT in the teaching and learning of mathematics: (1) the tool function for doing mathematics, which refers to outsourcing work that could also be done by hand, (2) the function of learning environment for practicing skills, and (3) the function of learning environment for fostering the development of conceptual understanding, as depicted in figure 4. Meanwhile, Amarasinghe and Lambdin (2000) add another aspect to the use of ICT in the teaching and learning of mathematics, i.e., to integrate mathematics with authentic context for a meaningful and contextual learning.

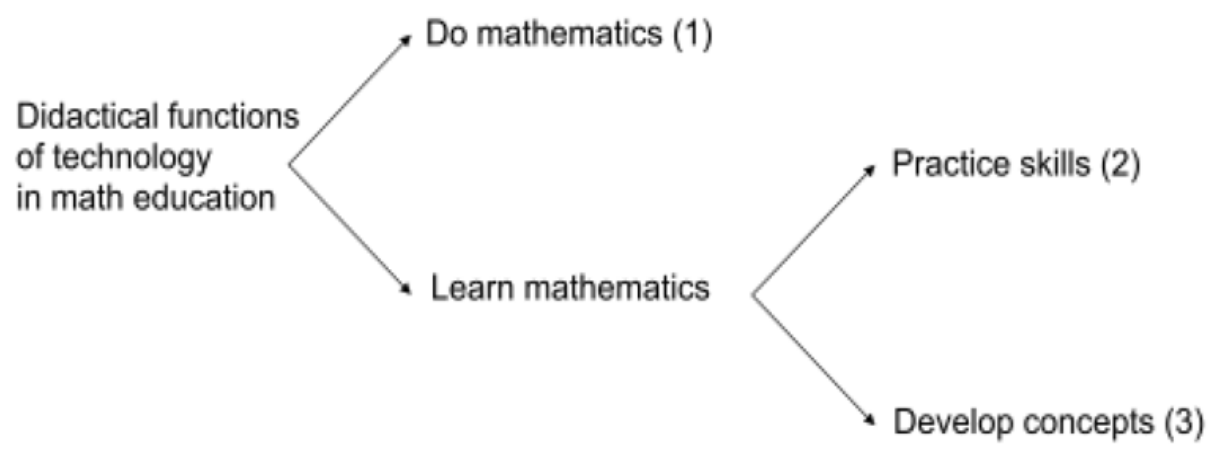

Figure 4: Functions of ICT in Mathematics Education (Drijvers, Boon \& Van Reeuwijk, 2010) 
Rahman, Ghazali, and Ismail (2003) describe the main purpose of mathematics teaching and learning as to develop the ability to solve a wide variety of complex mathematics problems. The process of problem solving involves understanding the problem, devising a plan or solution based on deductive or inductive analysis and mathematical model, implementing the plan and looking back (examining the solution). The skills required for these processes include communicating and expressing ideas through symbols, tables, diagrams, and other mathematical illustrations; and mathematical characters such as curiosity, motivation, and interest in learning mathematics; resilience and confidence in using mathematics to solve problems (Wardhani \& Sutanti, 2008). Karnasih (2008) explains the objectives of the teaching and learning mathematics, i.e., to achieve the mathematical power to include competencies in mathematical communication; mathematical reasoning; mathematical problem solving; mathematical connections; and positive attitudes towards mathematics.

ICT is able to provide strong support for all the above-mentioned requirements and there are now many outstanding examples of world class settings for competency and performance-based mathematics curricula that make sound use and integration of ICT in the teaching and learning process. The fact is that ICT in various forms of technology has been used for the teaching and learning of mathematics for more than 35 years as claimed by Pustari (2014). Mathematical software programs have been the most used of ICT in the teaching and learning of mathematics.

Ekawati (2008) states that integration of ICT in the teaching and learning of mathematics increases students motivation in learning mathematics, allows individual learning based on an individual's learning style and pace, and it has been excellent in increasing the cognitive and affective skill as compared to the traditional teaching and learning process. Technology can save time and gives students access to powerful new ways to explore concepts at a depth that has not been possible in the past. Weaker students often are better able to succeed with the help of ICT since they can do more exercises; and drills and practices at their own pace, and based on their individual learning styles.

Wahyudi (2008) states that the challenge for schools and teachers is not whether they use ICT or not but how they use it. ICT must not be considered as a mere technological tool, but it must be linked to educational goals, objectives, and learning outcome to be effective. Furthermore, it has to be well designed into the teaching and learning process - it 
should be well integrated. Thus, the use of ICT has a specific designated function to achieve a certain learning outcome in the learning process.

According to Wahyudi (2008), using ICT in mathematics classroom provide ample learning opportunities for the students at all stages of learning including the introduction, information presentation and acquisition, as well as assessment and evaluation stage. First, the ICT enable students to learn from feedback. The computer (ICT) often provides fast and reliable feedback which is non- judgmental and impartial. This can encourage students to make their own conjectures and to test out and modify their ideas. Secondly, the ICT (e.g. computers and calculators) enables students to produce many examples when exploring mathematical problems. This supports their observation of patterns and the making and justifying of generalizations. Thirdly, the ICT help students to see pattern and connection. The computer enables formulae, tables of numbers and graphs to be linked readily. Changing one representation and seeing changes in the others helps students to understand connections between them. Fourth, the use of ICT allows students to work with dynamic images that cannot be done within traditional teaching. Students can use computers to manipulate diagrams dynamically. This encourages them to visualize the geometry as they generate their own mental images. Fifth, using ICT (e.g. computers) enables students to work with real data which can be represented in a variety of ways. This supports interpretation and analysis that lead students to higher order thinking skills.

\section{What technology and how to integrate in the teaching and learning of mathematics?}

Changes brought by the integration of ICT in the teaching and learning of mathematics can be seen at two levels: ICT for learning mathematics, and new strategies for teaching mathematics with ICT. When a teacher uses ICT for learning mathematics, s/he can still design the teaching in an old- fashion way of face-to-face classical teaching, thus ICT is a mere technological tool which can assist students to learn, to do drill and practices, to do exercises on certain concepts in mathematics. In this context, As Pustari (2014) states, mathematical software programs have been the most used of ICT in the teaching and learning of mathematics, e.g., Geogebra, Autograph, Maple, Mathematica, MathLab, Wolfram Alpha, Desmos graphing calculator, Microsoft Mathematics, etc., whether it is a free software or commercial ones. In addition, there are also mathematical content repositories being offered online, that enable teachers to use them in the teaching and learning 
process, or for students to download or directly learn from it at their own time and pace, e.g., Khan Academy, m-Edukasi, Rumah Belajar, Youtube, classroom2.0, IXL, etc.
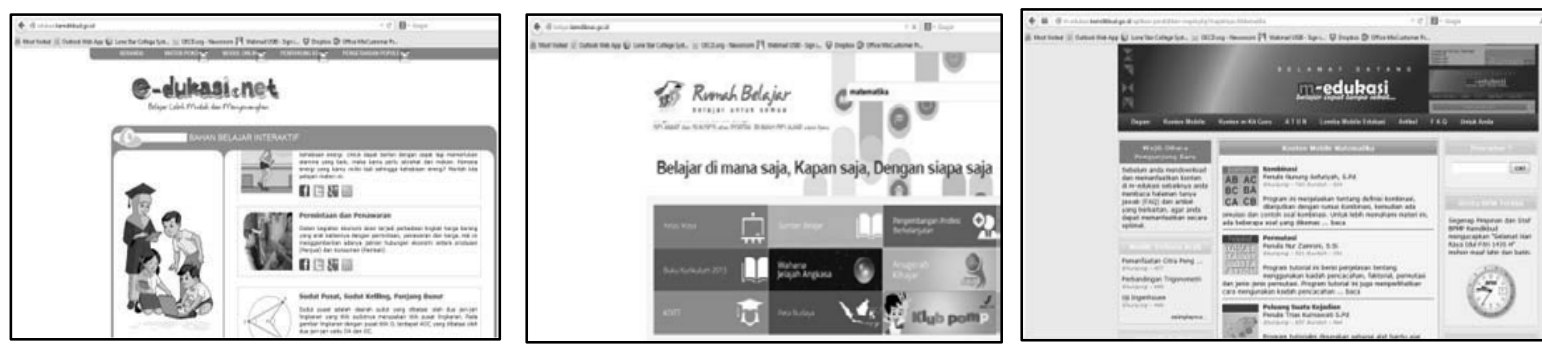

Figure 5: Examples from the Internet

When a teacher uses ICT to enable her/him to employ new strategy of teaching mathematics, students will eventually learn mathematics using ICT, as modeled by the flip learning strategy. Thus, with the availability of the mathematical software programs, the teaching and learning of mathematics can be designed differently and creatively, allowing both students and teachers to take advantage of the ICT enabled learning. My favorite websites for teaching and learning strategies have been EmergingEdTech (http://www.emergingedtech.com) and Edutopia (http://www.edutopia.or). Both these sites share ideas on how to teach using various new technologies, emerging technologies, and also new software programs to teach specific content.

There are many other resources available in the internet that mathematics teachers can use. Carefully selected and designed, these resources can transform the teaching and learning mathematics in any classroom or even beyond classroom. The following figure is an array of programs that can be used to foster collaboration in any learning process.

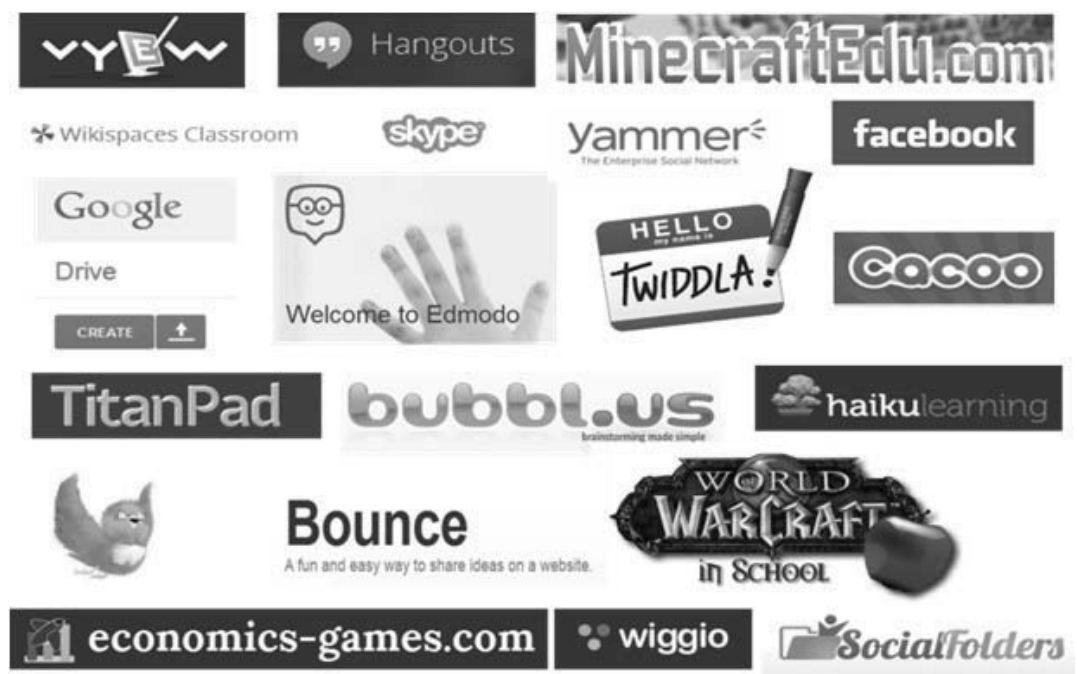

Figure 6: Array of possibilities 
In addition, there are also examples of the teaching and learning of mathematics using ICT, such as the ones provided by http://www.pilnetwork.com/Resources/LearningActivities. These examples demonstrate strategies, tips, and techniques of teaching and learning of mathematics which teachers can replicate or adapt to their own needs in their teaching.

With the abundance of resources available for both teachers and students in teaching and learning mathematics, specific skill is required for teachers and students to be able to select and adapt the resources into their own teaching and learning process, i.e., the so-called “information evaluation skill”. This skill will equip teachers and students to select carefully the resources from various perspectives, including validity of the concept or information, the breadth and depth of the information, the language, communication and presentation style, and also the visual presentation (image, animation, navigation, domain composition, etc.). This skill is important to assure the quality of the software/games/presentation (video, etc.) that is being selected for the teaching and learning of mathematics is valid, reliable, and of high quality and that it matches the learning outcome, does not contain prohibited materials or images, and is suitable for the teaching and learning of mathematics at the intended level for the intended audience.

\section{Into the Future}

According to Daly (2013), the future of learning with ICT is about access, anywhere learning and collaboration, both locally and globally. Teaching and learning process is going to be social activities. Access will open the door for both teachers and students to the rich and abundance educational resources available in the internet. Learning can take place in the classroom as well as beyond. Face-to-face meeting will be important for assessing and confirming students understanding through discussion with teachers, project and group activities with their peers. However, virtual learning through the internet is also of high importance where students will gain more information from their network via virtual teachers, virtual peers, etc. This arrangement was not be possible one or two decades ago, without the presence of ICT in its various forms.

The NMC Horizon Report (Johnson, et al., 2014) claims that the development of technology in education will be Bring Your Own Devices (BYOD), Cloud Computing, Games and Gamification, Learning Analytics, The Internet of Things and Wearable Technology. 
BYOD or Bring Your Own Technology means the school does not have to provide personal devices anymore. BYOD is still rare in Indonesia, except in big cities where students can afford to have their own devices. Nevertheless, there is also constraining school regulations which do not allow students to bring smartphone or personal mobile phones into the classroom, since some teachers still consider those gadgets as disruptive to the teaching and learning process.

Cloud Computing refers to expandable, on demand services and tools that are served to the user via the Internet from specialized data centers and consume almost no local processing or storage resources. Cloud computing resources support collaboration, file storage, virtualization, and access to computing cycles (Johnson, et al., 2014). Using the cloud, a school does not need a big server of its own, and students may not need to carry flash storage anymore. Everything can be stored in the cloud, to be available anywhere, anytime, and by anybody. At present, cloud computing is gaining its popularity in Indonesia, especially in higher education institutions and government and private offices.

Games and gamification. According to the NMC Report (Johnson, et al., 2014), the gaming industry is producing a steady stream of games that continue to expand in their nature and impact. They can be artistic, social, and collaborative, with many allowing massive numbers of people from all over the world to participate simultaneously. The cognitive, motivational, emotional, and social impact video games on human behavior have also been highlighted. Gamification refers to the integration of gaming elements, mechanics, and frameworks into non-game situations and scenarios for training and motivational purposes, potentially for teaching and learning. In Indonesia, availability of games has also been increasing. The use of games in teaching and learning has been research sporadically, and also studied by SEAMOLEC. Apparently, it still needs some more time to gain support from educators to allow students effectively learned from a well-designed game.

Learning Analytics is an educational application of web analytics, a science that is commonly used by businesses to analyze commercial activities, identify spending trends, and predict consumer behavior, but currently is being used in education. The aims are for learner profiling, especially around individual student interactions in online learning activities. In Indonesia, much of this has been implemented in higher education institutions offering e-learning courses in a face-to-face setting as well as distance education mode. 
The Internet of Things is a network of connected objects that link the physical world with the world of information through the web. This application is still far from the world of education in Indonesia.

Wearable Technology refers to devices that can be worn by users, taking the form of an accessory such as jewelry, sunglasses, a backpack, or even actual items of clothing such as shoes or a jacket. A number of devices have been popular in Indonesia, especially the smartphone bangle/watch, and sport devices for bikers and walkers.

From the so many developments predicted by NMC (Johnson, et al., 2014) in K-12 teaching and learning, there are only a few that have been used and implemented or integrated into the teaching and learning process in Indonesia. It means that teachers in Indonesia have a lot to anticipate in what will be coming soon into their lives and transforming their teaching and learning practices

\section{Conclusion}

Zappa (2013) attempted to organize a series of emerging technologies that are likely to influence education in the upcoming decades. Despite its inherently speculative nature, the driving trends behind the technologies can already be observed, thus it is a matter of time before these scenarios start its way in our education environments. The infographic, designed by Michell Zappa is available from the site listed in the references as it is too complex to do justice here.

At present, according to Zappa, technology is fixed and centralized in a computer lab or classroom. This illustrates precisely the use of ICT in the teaching and learning of mathematics in Indonesia today, ICT is still being used relatively fixed to the teaching and learning in the classroom, instead of taking advantage of its mobility capacity. Gamification and opening of information which indicate the ubiquitous nature and mobile use of technology have been starting along with digitalization of classroom which allows students to do virtual collaboration. Although not as advanced as Singapore or Australia, these trends are already starting in Indonesia, especially in the big cities. Imperative efforts from Government to facilitate this movement to take place more evenly including the remote areas of Indonesia is needed. 
With Zappa's prediction, 10-30 years from now, teaching and learning and classroom will be quite different from the way it is today. There will be mass adoption of various forms of technology to leverage expert resources and connectivity. Significant numbers of learning activities are moving to individualized, just-in-time learning, and collaborative approaches. There will be a transition from classroom teacher-centered to hybrid or blended learning that combines e-learning components with less-frequent face-to-face class meetings. Assessment of learning will take into account more individually-oriented learning outcomes and capacities that are relevant to subject mastery and global competency. Teachers will hold a significant role as learning designer, incorporating the available resources into meaningful (virtual) learning experiences for students across the geography. At this point, we would be better readying ourselves as educators to anticipate this transformation, by transforming first ourselves. 


\section{References}

Amarasinghe, R., \& Lambdin, D. (2000) Uses of Computer Technology in Interdisciplinary Mathematics Learning. Presented at the International Conference on Learning With Technology, 8-10 Mar, 2000, Temple University, Philadelphia.

Amin, S.N. (n.d.) An Effective use of ICT for Education and Learning by Drawing on Worldwide Knowledge, Research, and Experience: ICT as a Change Agent for Education (A Literature Review). Retrieved from http://www.nyu.edu/classes/keefer/waoe/amins.pdf

Daly, J. (2013) A Map of Education Technology Through 2040 [\#Infographic]: How will disruptive technology change education? EdTech Magazine: Focus on Higher Education. Retrieved from: http://www.edtechmagazine.com/higher/article/2013/08/map-educationtechnology-through-2040-infographic

Drijvers, P., Boon, P., \& Van Reeuwijk (2010). Algebra and technology. In P. Drijvers (Ed.), Secondary algebra education. Revisiting topics and themes and exploring the unknown (pp. 179-202). Rotterdam: Sense.

Drijvers, P. (2012) Digital Technology in Mathematics Education: Why It Works (Or

Doesn't) Presented in the 12th International Congress on Mathematical Education, Seoul, South Korea, 8-15 July, 2012.

Ekawati, E. (2008). Pembelajaran Matematika Berbatuan ICT dalam Meningkatkan Kemampuan Kognitif dan Kemampuan Afektif Siswa. Jurnal Pendidikan Matematika (2008) Jakarta, PPPPTK Matematika

Harrison, C., Comber, C., Fisher, T., Haw, K., Lewin, C., et al. (2002). The impact of information and communication techonogies on pupil learning and attainment. Coventry: Becta. [on-line]. Retrieved from: http://partners.becta.org.uk/page_documents/research/ImpaCT2_strand1_bw.pdf

Hoyles, C., \& Lagrange, J.-B. (Eds.)(2010). Mathematics education and technology Rethinking the terrain. New York: Springer.

Johnson, L., Adams Becker, S., Estrada, V., \& Freeman, A. (2014). NMC Horizon Report: 2014 K-12 Edition. Austin, Texas: The New Media Consortium.

Johnson, B. (2014) Creating Learning Environments. Retrieved from: http://www.edutopia.org/blog/creating-learning-environments-ben-johnson.

Karnasih, I. (2008) Examples of the Use of ICT in Improving Teaching and Learning Mathematics and in Solving Problems of Teaching and Learning Mathematics. Presented in Seminar and Lokakarya Pembelajaran Matematika Berbasis Teknologi Informasi, Yogyakarta: PPPTK Matematika, 10-11 June 2008

Lukman, E. (2013a). Yahoo: Tablet owners in Indonesia prefer local news to celebrity gossip. Retrieved from: http://www.techinasia.com/yahoo-tablet-owners-indonesia-prefer-localnews- celebrity-gossip/

Lukman, E. (2013b). Report: Indonesia now has 74.6 million internet users; this is what they do online. Retrieved from: http://www.techinasia.com/indonesia-internet-usersmarkplus-insight/? utm_source=rss\&utm_medium=rss\&utm_campaign=indonesiainternet-users-markplus- insight

Microsoft (2014) 21CLD Learning Activity Rubrics. Innovative Teaching and Learning Research. Retrieved from: http://www.pil-network.com/PD/21CLD/Overview/

Nandika, D., Priowirjanto, G.H., \& Soekartawi (2007) Integrating ICT for Better Quality and Values of Education: Lesson from Indonesia. Paper presented at the Policy Forum of 42nd SEAMEO Council Conference, Bali, March 2007

National Council of Teachers of Mathematics (2008). The role of technology in the teaching and learning of mathematics. Retrieved from: http://www.nctm.org/about/content.aspx?id1/414233. 
Nizam \& Santoso, A. (2013). Indonesia: OER initiatives \& ICT in Teacher Training. Paper presented at the UNESCO-OER Follow up Meeting, Paris, 26-27 March._Retrieved from: http://www.unesco.org/new/fileadmin/MULTIMEDIA/HQ/CI/CI/pdf/news/indonesia_oe r_initiatives.pdf

Pannen, P., Riyanti, R.D., \& Pramuki, B.E. (2007). HYLITE Program: An ICT-based ODL for Indonesian Teachers Education. Presented at the 11th UNESCO APEID Conference on Revitalizing Higher Education, Dec. 12-14, 2007, Bangkok, Thailand Retrieved from: https://www.academia.edu/4867606/ HYLITE_Program_An_ICTbased_ODL_for_Indonesian_Teachers_Education_1

Pannen, P. (2009). E-Learning: An Introduction. Presented at the E-Learning Workshop for lecturers of Universitas Indonesia, Jakarta, May 12, 2009.

Pustari, M. (2014). Pengaruh Penggunaan Microsoft Mathematics Terhadap Hasil Belajar Siswa Kelas XI IPS Pada Mata Pelajaran Matematika Materi Turunan Fungsi. Unpublised Thesis. STKIP Kebangkitan Nasional, Jakarta.

Rahman, S.A., Ghazali, M., \& Ismail, Z. (2003) Integrating ICT In Mathematics Teaching Methods Course: How Has ICT Changed Student Teachers' Perception About Problem Solving. The Mathematics Education into the 21st Century Project. Proceedings of the International Conference: The Decidable and the Undecidable in Mathematics Education. Brno, Czech Republic. Retrieved from: http://www.math.unipa.it/ grim/21_project/21_brno03_AbdulRaman.pdf

Suryadi, A. (2007). Pemanfaatan ICT Dalam Pembelajaran. Jurnal Pendidikan Terbuka dan Jarak Jauh, 8(1), 83-98

UNESCO Institute for Statistics (2014) Information and Communication Technology (ICT) in Education in Asia: A comparative analysis of ICT integration and e-readiness in schools across Asia. Bangkok: UNESCO Institute for Statistics.

Wahyudi (2008) What does research say on the use of ICT to improve the teaching and learning of mathematics? Presented in Seminar and Lokakarya Pembelajaran Matematika Berbasis Teknologi Informasi Yogyakarta: PPPTK Matematika, 10-11 June.

Wardhani, S.,\& Sutanti, T. (Ed). (2008). Analisis SI dan SKL Mata Pelajaran Matematika SMP/MTs untuk Optimalisasi Tujuan Mata Pelajaran Matematika. Yogyakarta: Pusat Pengembangan dan Pemberdayaan Pendidik dan Tenaga Kependidikan Matematika Zappa, M. (2013). Envisioning the future of educational technology. Retrieved from:

http://envisioning.io/education/ 